\title{
THE EFFECT OF MESTRANOL AND LYNOESTRENOL ON OVARIAN HISTAMINE IN THE RAT
}

\author{
A. ABDEL-AZIZ,* A. GHAZAL AND TAHIA DAABEES \\ Department of Pharmacology, Faculty of Pharmacy, University of Alexandria, \\ Alexandria, Egypt Arab Republic
}

(Received 4th April 1974)

\begin{abstract}
Summary. The effect of oral treatment of rats for 12 days with the contraceptive steroids, mestranol $(0.08 \mathrm{mg} / \mathrm{rat} /$ day $)$ and lynoestrenol $(2.5 \mathrm{mg} / \mathrm{rat} /$ day $)$ alone and in combination, on ovarian histamine content was studied. All treatments resulted in a decrease in the histamine content per ovary, but this was only significant for mestranol alone. When the results were expressed in terms of histamine per $\mathrm{g}$ ovary, treatment with mestranol resulted in a significant decrease while lynoestrenol and mestranol plus lynoestrenol treatment resulted in a nonsignificant increase.
\end{abstract}

Hormonal influence on ovarian histamine and the rôle of this biogenic amine in ovarian function has received little attention. Lipner (1971) reported that ovarian histamine in immature rats was undetectable, but that treatment with PMSG and HCG caused an increase. Szego \& Gitin (1964) found that ovarian histamine was depleted in the rat during the ovarian hyperaemic response to LH.

The mode of action of oral contraceptive steroids has been much studied but there are no available data on the effect of these contraceptives on ovarian histamine. The present work was undertaken to investigate the effect of two contraceptive steroids, mestranol and lynoestrenol, on the histamine content of rat ovaries.

One hundred and twenty virgin female albino rats with a mean body weight of $130 \pm 5 \mathrm{~g}$ were allocated equally to four groups. The animals selected showed regular oestrous cycles. The contraceptive steroids were administered orally and were suspended in $0.5 \%$ carboxymethylcellulose (CMC). Treatment was started when the animals were in natural oestrus and was continued for 12 consecutive days, the daily dose being suspended in $0.2 \mathrm{ml} \mathrm{CMC}$. The first group received $0.08 \mathrm{mg}$ mestranol/rat/day, the second group received $2.5 \mathrm{mg}$ lynoestrenol $/ \mathrm{rat} / \mathrm{day}$, the third group received $0.08 \mathrm{mg}$ mestranol $+2.5 \mathrm{mg}$ lynoestrenol/rat/day and the fourth group received corresponding volumes of $0.5 \% \mathrm{CMC}$. At the end of the treatment period, the animals were killed, and their paired ovaries were quickly removed, placed on ice and dissected free of fat and surrounding tissues. After blotting, the ovaries were accurately weighed

\footnotetext{
* Present address: Department of Pharmacology, Faculty of Medicine, University of Aleppo, Aleppo, Syrian Arab Republic.
} 
to the nearest $0.1 \mathrm{mg}$. In each group, three sets of pooled ovaries, each from ten animals, were extracted for histamine. The histamine extraction was carried out as described by Parrat \& West (1957), using trichloroacetic acid, and was assayed biologically using the guinea-pig ileum suspended in Tyrode's solution in the presence of atropine sulphate $\left(1 \times 10^{-7} \mathrm{~g} / \mathrm{ml}\right)$ essentially as described by Barsoum \& Gaddum (1935). At the end of each assay, the specificity of the substance causing the ileum to contract was checked by the addition of the antihistaminic drug, mepyramine maleate $\left(1 \times 10^{-7} \mathrm{~g} / \mathrm{ml}\right)$, as described by Reuse (1948).

The ovarian histamine content was expressed in terms of $\mu \mathrm{g}$ histamine base per $\mathrm{g}$ ovary and per ovary.

The effect of contraceptive steroids on ovarian histamine is shown in Table 1. Treatment with mestranol or lynoestrenol alone, or with mestranol+lynoestrenol resulted in a decrease in the histamine content per ovary. The per-

Table 1. Effect of treatment with mestranol and lynoestrenol separately or in combination on ovarian histamine in rats

\begin{tabular}{|c|c|c|c|c|c|c|c|c|}
\hline \multirow[b]{2}{*}{ Group } & \multicolumn{8}{|c|}{ Ovarian histamine } \\
\hline & \multicolumn{2}{|c|}{$\begin{array}{l}\text { Controls } \\
\lg \quad \mu g / \text { ovary }\end{array}$} & \multicolumn{2}{|c|}{\begin{tabular}{l}
\multicolumn{2}{c}{ Mestranol } \\
$\mu \mathrm{g} / \mathrm{g} \quad \mu \mathrm{g} /$ ovary
\end{tabular}} & \multicolumn{2}{|c|}{$\begin{array}{l}\text { Lynoestrenol } \\
\mu \mathrm{g} / \mathrm{g} \quad \mu \mathrm{g} / \text { ovary }\end{array}$} & \multicolumn{2}{|c|}{$\begin{array}{c}\text { Mestranol }+ \text { lynoestrenol } \\
\mu \mathrm{g} / \mathrm{g} \mu \mathrm{\mu g} / \text { ovary }\end{array}$} \\
\hline $\begin{array}{l}1 \\
2 \\
3\end{array}$ & $\begin{array}{l}4 \cdot 00 \\
4 \cdot 05 \\
4 \cdot 10\end{array}$ & $\begin{array}{l}0.122 \\
0.088 \\
0.087\end{array}$ & $\begin{array}{l}2 \cdot 90 \\
3 \cdot 15 \\
3 \cdot 69\end{array}$ & $\begin{array}{l}0.054 \\
0.054 \\
0.062\end{array}$ & $\begin{array}{l}3.29 \\
5 \cdot 69 \\
3.93\end{array}$ & $\begin{array}{l}0.069 \\
0.088 \\
0.055\end{array}$ & $\begin{array}{l}4 \cdot 50 \\
4 \cdot 34 \\
3 \cdot 96\end{array}$ & $\begin{array}{l}0.092 \\
0.077 \\
0.050\end{array}$ \\
\hline $\begin{array}{l}\text { Mean } \\
\pm \text { S.E. }\end{array}$ & $\begin{array}{l}4 \cdot 05 \\
0.03\end{array}$ & $\begin{array}{l}0.099 \\
0.01\end{array}$ & $\begin{array}{l}3.25 \\
0.23\end{array}$ & $\begin{array}{l}0.057 \\
0.003\end{array}$ & $\begin{array}{l}4 \cdot 30 \\
0 \cdot 72\end{array}$ & $\begin{array}{l}0.071 \\
0.01\end{array}$ & $\begin{array}{l}4 \cdot 27 \\
0 \cdot 16\end{array}$ & $\begin{array}{l}0.073 \\
0.01\end{array}$ \\
\hline$P$ & - & - & $<0.05$ & $<0.05$ & $>0.05$ & $>0.05$ & $>0.05$ & $>0.05$ \\
\hline
\end{tabular}

The $P$ values indicate the level of the significance of differences between the means of control and treated animals. For number of rats and number of ovaries, see text.

centage histamine depletion observed after treatment with mestranol, lynoestrenol and with mestranol+lynoestrenol was $42 \%, 28 \%$ and $26 \%$, respectively. Only after mestranol treatment, however, was this depletion significant. Treatment with contraceptive steroids resulted in a significant decrease in ovarian weight $/ 100 \mathrm{~g}$ body weight as well as in ovarian weight $(\mathrm{mg}) / \mathrm{rat}$ $(P<0.001)$. Thus, when the results were expressed in terms of ovarian histamine per $g$, only mestranol treatment resulted in a significant decrease while lynoestrenol and mestranol + lynoestrenol treatment resulted in a non-significant increase (Table 1).

The occurrence of histamine in rat ovaries was reported by several workers (Szego \& Gitin, 1964; Hunter \& Leathem, 1968; Lipner, 1971). Schayer (1962) provided evidence that histamine is an intrinsic regulator of the microcirculation. The rôle of histamine in relation to ovarian function is not yet known, but Hunter \& Leathem (1968) suggested that it may be involved in regulation of the microcirculation of the ovary. Histamine depletion was found to occur in rat ovaries in the hyperaemic response to LH (Szego \& Gitin, 1964). The results obtained in the present work showed that it is only mestranol which caused a significant depletion of ovarian histamine whether the results were 
expressed in terms of $\mu$ g histamine per ovary or per $\mathrm{g}$ ovary. Mestranol is a potent oestrogen and its effect on ovarian histamine parallels the action of oestrogen on uterine histamine (Szego, 1966; McKercher, Van Orden, Bhatnagar \& Burke, 1973). The decrease in ovarian histamine after treatment with mestranol may reflect changes in histamine-forming and/or histamineinactivating enzymes. There are no available data about histamine formation and the nature of the inactivating enzymes in the ovary. Histamine depletion in the ovary after mestranol treatment may be related to changes in mast cell count which was reported to decrease in the uterus following treatment with oestrogen (McKercher et al., 1973), but it is still not known whether the ovarian histamine is, in fact, of mast cell origin. The results also showed that lynoestrenol, possibly through its progestational action, did not decrease ovarian histamine and actually resulted in a non-significant increase. In addition, it antagonized the effect of the oestrogenic mestranol on ovarian histamine. It can be inferred, therefore, that as far as treatment with the combined steroids is concerned, there is probably no causal relationship between their antifertility effect and their action on ovarian histamine as the latter did not change significantly following such treatment. It was reported by Lipner (1971) that ovulation occurred following histamine depletion of the ovaries, but that the number of ova shed was reduced. It has been found (A. Abdel-Aziz, A. Ghazal and $T$. Daabees, unpublished data), that treatment with mestranol and lynoestrenol alone or in combination resulted in a significant depletion of uterine histamine and this may, to some extent, be related to the antifertility effect of these steroids.

\section{REFERENCES}

Barsoum, G. S. \& Gaddum, J. H. (1935) The pharmacological estimation of adenosine and histamine in blood. F. Physiol., Lond. 85, 1.

Hunter, F. \& Leathem, J. H. (1968) Histamine concentration in normal and cystic rat ovaries. Endocrinology, 82, 171.

Lipner, H. (1971) Ovulation from histamine depleted ovaries. Proc. Soc. exp. Biol. Med. 136, 111.

MaKercher, T. G., Van Orden, L. S., Bhatnagar, R. K. \& Burke, J. P. (1973) Estrogen-induced biogenic amine reduction in rat uterus. 7. Pharmac. exp. Ther. 185, 514.

Parrat, J. R. \& West, G. B. (1957) 5-Hydroxytryptamine and mast cells. J. Physiol., Lond. 137, 169.

Reuse, J. J. (1948) Comparison of various histamine antagonists. Br. F. Pharmac. Chemother. 3, 174.

SCHAYER, R. W. (1962) Evidence that induced histamine is an intrinsic regulator of microcirculatory system. Am. 7. Physiol. 202, 66.

Szego, C. M. (1966) Role of histamine in mediation of hormone action. Fedn Proc. Fedn Am. Socs exp. Biol. 24, 1343.

Szego, G. M. \& Gitin, E. S. (1964) Ovarian histamine depletion during acute hyperaemic response to luteinizing hormone. Nature, Lond. 201, 682. 